DOI 10.14746/ppuam.2019.9.14

Martin Hapla

\title{
Is Separation of Powers a Useless Concept? Part II: Tripartite System Criticism and Application Problems ${ }^{1}$
}

\section{Introduction \\ The Separation of Powers as a "Metaphysical" Concept}

The idea of the separation of powers has never been completely free of criticism, and it is interesting that this critique was often directed at its abstract and fictitious nature. There were authors who did not hesitate to call it a chimera ${ }^{2}$ or compare its three-component variants with the theological doctrine of the Holy Trinity. ${ }^{3}$ For example, Léon Duguit explicitly stated that it is a metaphysical concept analogous to that religious construction, which is as such unacceptable in the positive theory of law. ${ }^{4}$ However, if we want to refer to metaphysics, we must be aware that it is a difficult-to-grasp concept that is often used for negative labelling. Something similar, in the context of science, could also be said about references to theology, chimeras, etc. These are negative connotations we should avoid, yet this is not to say that there are no rational objections behind these connotations that we should try to explore.

In my view, the separation of powers can be factually disputed by pointing out that it does not actually fulfil its objectives, (it is not efficient in their fulfilment), and that it is an unnecessarily complex construction which, in some of its features, does not reflect the logical context, (e.g. its tripartite structure). For now, we understand both these objections as hypotheses to be explored. A third complementary assumption can then be stated about its attraction: its attraction actually lies in the fact that it is a suggestive, rhetorically impressive concept. In other words, its three-member structure was successful

1 The paper is an output from the project Nové teorie dělby moci code: MUNI/A/0736/2017.

2 J. A. Fairlie, The Separation of Powers, "Michigan Law Review"1923, no. 4, p. 419.

3 Ibidem, p. 435.; Ch. Möllers, The Three Branches. A Comparative Model of Separation of Powers, Oxford 2013, p. 16.

4 J. A. Fairlie, op. cit., p. 420. 
not because it structured public authorities clearly and exhaustively into clearly defined entities, but because such a construction evokes strong feelings - it has an "aesthetic" effect on us. It is therefore not an adequate description but an effective figure.

Is it even possible to prove any of these claims? I have already pointed out in the previous paper ${ }^{5}$ how evaluating the efficiency of the separation of powers is difficult as there are too many factors involved in the realization of good governance. It is then difficult to evaluate the fulfilment of objectives that lead to it, (such as a balanced position among various state bodies). Our confidence in this idea ultimately relies on the simple assumption that the proper functioning of a system requires some degree of control and diversification. Although the components of the separation of powers do lead to it, the problem remains what the correct rate is. In this respect, classical theories do not help us too much. In its execution, it is therefore more convenient to perceive the separation of powers are as a bet or experiment through which we aim at achieving certain positive effects. I would like to give two comparisons about our ability to evaluate its functioning: When standing on the remains of a burnt house, we can easily find out that a fuse blew. However, we do not know whether it worked at a time when there were no electricity problems. The same applies to the separation of powers - when a dictatorship is established in the country, we can easily see that the separation of powers has been destroyed. However, we do not know and cannot even know if our institutional design works when there are no serious threats to it.

Compared to evaluating efficiency of institutional design, it is still a bit easier to demonstrate the lack of its logical connections, which issue will be discussed in the following section. Now let's take a look at the thesis of rhetorical impressiveness and suggestiveness of the separation of powers. Can we prove this, or is this one those situations when we cannot say what the source of its obvious attraction is and so we resort to using such statements? This cannot be excluded either. The problem is that the reflection of such action can only be sought in our feelings, or generalizations of their expression by people. We can point out that number three is a magic number that often occurs in various stories and works of art: three rods of the Great Moravian ruler Svatopluk ${ }^{6}$; the three Musketeers; and fairy-tale kings usually have three daughters or sons. The identification of such narrative elements supports that thesis to a certain extent. Still, this can be nothing more than pure coincidence - the concept could be both logical and rhetorically or otherwise impressive at the same time. It deserves harsh criticism only if it is illogical

5 M. Hapla, Is Separation of Powers Useless Concept? Part I: Components and Purpose of Separation of Powers, "The Adam Mickiewicz University Law Review" 2018, vol. 8.

6 For the original story of Svatopluk's three rods by Konstantin Porphyrogenate, see D. Bartoňková et al. eds., Magnae Moraviae fontes historici III. Diplomata, epistolae, textus historici varii, Brno, 1969, pp.398-399. It is worth mentioning that the very strong use of the number three symbolism throughout the story, together with other reasons, led some to a conclusion that the story is mere literary fiction and not a description of any real event. 
and its suggestiveness is meant to hide it. Everything thus seems to lead to whether the separation of powers is or is not a logical concept. The outcome should lead to the evaluation of to what extent it is mere "metaphysical" nonsense. Attention will be focused on two areas of problems: tripartite system criticism and some application problems of the principle of separation of powers.

\section{The Problematic Nature of the Tripartite Separation of Powers}

A question was raised above whether the separation of powers is a logical concept, and so it is necessary to analyse it in more detail now, (at least in a slightly narrower framework): one of the most influential concepts of the separation of powers is the tripartite concept, as already outlined by Montesquieu. ${ }^{7}$ In its context, the judiciary is perceived as one of the key components of state organization. But are we even able to define the judicial function as something specific enough?

Gradually, a number of concepts emerged that either postulated the existence of only two powers or claimed that there are more than just three. There are also four-member and five-member concepts. ${ }^{8}$ In spite of that, however, the three-member concept has retained the greatest popularity of all of them, which then soon reflected in the design of some constitutions. ${ }^{9}$ This, however, did not silence the doubts connected with it.

In this context, notable is the critique by František Weyr who perceived as logical the bipartite concept while, according to him, the tripartite concept was, "a mere schema arranged in line with the commonly appearing organization of the legal orders of certain (empirical) states." ${ }^{10}$ If we want to properly categorize individual state functions, we must first find their unifying elements. In Weyr's view, the notion of law-making is one of them, "the legislative function is the creation of primary norms (i.e., statutes in the usual sense), while the judiciary and executive functions are the creation of secondary norms (court rulings, administrative and private law decisions) which at the same time appears to be the execution (application) of primary norms." ${ }^{11}$ This division removes ${ }^{12}$ the

7 C. Montesquieu, The Spirit of Laws, Kitchener 2001, p. 173.

8 Five powers were distinguished, for instance, by one of the leading authors of the French liberal school Benjamin Constant. For details, v. J. A. Fairlie, op. cit., p. 409.

9 Explicit references to the division of powers into three different branches (legislative, executive, and judicial) were included, for example, in some of the first constitutions of American states. There were, for example, the Constitution of Maryland of 1776, the Constitution of Massachusetts of 1780, and the Constitution of New Hampshire of 1783. See J. A. Fairlie, op. cit., p. 397.

10 F. Weyr, Teorie práva, Praha 2015, p. 244.

11 F. Weyr, Československé právo ústavní, Praha 1937, p. 21.

12 Ibidem, p. 22. 
difference between the executive and the judicial function, and the tripartite concept is necessarily replaced by the bipartite concept. ${ }^{13}$

It is worth noting that the current approaches tend to distinguish more state functions rather than limit them. Today's functions of state bodies ${ }^{14}$ are perceived as too varied to fit into Montesquieu's three categories, for instance, by Eoin Carolan. ${ }^{15}$ This, however, does not challenge the logic of Weyr's approach as it does not say that the individual functions in his two-category concept cannot be further broken down. And this would not be anything new as there are many authors in the past who proposed the bipartite concept and further structured the executive component in more detail. For example, Pradier-Fodéré distinguished between the legislative and executive powers, which he then further divided into the judiciary and administrative powers. ${ }^{16}$ Théophile Ducrocq even distinguished between three executive branches - governmental, administrative, and judicial ${ }^{17}$ - within the executive power.

So how exactly should we deal with the position of the judicial function? Can we place it at the same level as the legislative and executive functions or should we understand it as one of the sub-categories of the latter? Montesquieu himself saw the essence of the judicial function in deciding the facts, ${ }^{18}$ which, of course, is not sufficient for its distinction. We could even say that this is highly misleading - it is not excluded that Montesquieu, as part of his reflection on the English government system, confused judges with members of the jury, as Robert Stevens believes. ${ }^{19}$

In František Zoulík's opinion, Ernst Friesenhahn found a criterion in the "dispute over law" 20 that allows us to distinguish the judiciary from public administration. As he states himself, "The possibility of this dispute arises (irrespective of the legal branch) from the basic construction of subjective law as a relationship between different legal entities; this gives the opportunity for one entity to act in its own interest towards another entity of the same relationship. The solution to this dispute can only be carried out by an entity standing outside the legal relationship from which the dispute arose and

13 Compare Ibidem, pp. 21-32.

14 E. Carolan, The New Separation of Powers: A Theory for the Modern State, New York 2009, p. 42, 257. To this, cf. also M. J. C. Vile, Constitutionalism and the Separation of Powers, Indianopolis 1998, p. 16.

15 M. J. Vile puts the crisis of the three-member concept of the separation of powers into the context of the development of bureaucracy, starting from the early 20 th century. To this cf. M. J. C. Vile, op. cit., pp. 6-7.

16 J.A. Fairlie, op. cit., pp. 418-419.

17 Ibidem, p. 419.

18 L. Claus, Montesquieu's Mistakes and the True Meaning of Separation, "Oxford Journal of Legal Studies" 2005, no. 3, p. 423.

19 R. Stevens, A Loss of Innocence?: Judicial Independence and the Separation of Powers, "Oxford Journal of Legal Studies"1999, vol. 19, No.3, p. 375.

20 F. Zoulík, Soudy a soudnictvi, Praha 1995, p. 17. 
which plays the role of an impartial 'third party". ${ }^{21}$ Zoulík then sees this third party in courts and specifies the idea by asserting that although administrative bodies also apply law, they do it inside the legal relationship. In other words, they differ from courts in that they apply law in public interest and not in order to resolve the dispute. ${ }^{22}$

This distinction can really help us to distinguish courts from administrative bodies. At the same time, it does not necessarily rebut Weyr's bipartite concept of state functions but rather points to the need for its further breakdown, (even the application of law by a court is the execution of primary norms in case of the dispute over the law). It also raises the question of at what level the separation of functions should be applied. It is interesting that one of the main objections against the above definition consisted in the fact that many of the powers that the courts have overlapped the concept of the dispute over the law. According to Zoulik, this is not a bad thing because entrusting certain things into the power of the courts may be subject to various reasons. Therefore, this does not challenge the "dispute over the law" as a defining criterion of the judiciary. ${ }^{23}$ Although this assertion is basically correct, it makes the applicability of the principle of the separation of functions highly problematic, and this principle is again not consistently implemented.

Finally, it is worth mentioning another argument that is used to support the specific status of the judiciary in relation to the legislative and executive component - the question of the expert nature of its activities. Maxim Tomoszek states that the judiciary is an expert power that should decide on legal rather than political issues. ${ }^{24}$ Leaving aside the fact that sometimes there can be a very thin border between law and politics ${ }^{25}$, we can still argue that most administrative bodies do not solve political problems in their ac-

21 Ibidem, pp. 17-18. For completeness, it should be added that Zoulík sometimes referred to the "dispute over the law" also as "legal conflict." The reason for this terminological shift was his attempt to eliminate some traditional criticism toward this concept. Still, I do not see this shift as fortunate because it is a concept with very vague boundaries, which even the author himself did not define sufficiently. For details, see Ibidem, pp. 18 - 19. Generally, however, we can say that dispute-solving is generally considered the primary task of the judiciary. This concept can be found, for example, in T. Schei, The Independence of Courts and Judges and Their Relationship with the Other Branches of Government, in: The Independence of Judges, eds. N. A. Engstad, A. Frøseth, B. Tønder, Hague 2014, p. 4.

22 F. Zoulík, op. cit., p. 18.

23 Ibidem, p. 19.

24 M. Tomoszek, Délba moci jako podstatná náležitost demokratického prárního státu, in Délba moci. Sbornik príspèvkui sekce uistavního práva, přednesených na mezinárodni védecké konferenci Olomoucké práonické dny 2013, ed. J. Jirásek, Olomouc 2014, pp. 245-246.

25 Unfortunately, Zoulik, who also perceives courts as a certain barrage of law against the turbulent waters of politics, did not sufficiently reflect this fact in his work. To this, see, e.g., F. Zoulík, op. cit., p. 74. Personally, I admit that the judiciary plays this role to a certain extent, especially if we perceive politics as an activity developed by certain interest groups within political parties. To me, it does not seem appropriate to use it as a distinctive criterion, among other things also because some rulings of constitutional courts can be very political in nature. 
tivities and require a certain, (sometimes great), degree of expertise for their operations. Yet, it is the distinction between courts and administrative bodies that is the biggest problem. Expertise is certainly one of the characteristics of modern courts, ${ }^{26}$ but it is not enough to distinguish them from other organizational components of the state, and the same applies to their activities. The tripartite concept of the separation of powers thus can hardly be called logical.

\section{Approaches to Solving the Application of the Separation of Powers}

In general, we can say that the problems associated with the practical applications of the idea of the separation of powers are many, as is the case of the approaches to their solution. The main problem can be seen in that we cannot derive clear applications to specific facts from its traditional form. This can be well illustrated on the tension that exists between its individual components: There is no standard that would allow us to distinguish when to prioritize the institutional independence of a state body or, on the contrary, its control through the system of checks and balances. In other words, when we should perceive intervention by one state body into another state body as negative interference with its independence, and when we should perceive it as a positive check or balance. ${ }^{27}$ This inability to draw clear practical consequences can also be perceived as one of the main sources of criticism of the separation of powers as a fictitious construction.

There are basically three solutions to this situation:

1) To accept the open-ended nature of the separation of powers and, when a particular case demonstrates the need to supplement it, to do so through a decision of a state body. More precisely, this is a situation where the state body has no real theory at hand that would allow us to specify the separation of powers as a standard, and therefore this body must specify the separation of powers by its own decisions, the reasons for which can only be speculated on. They might be based on the emotions of judges or on general reasons that we cannot accept as part of any theory of the separation of powers. By this, the problem at hand transforms into the question of which state body is legitimate to make such decisions and for what reasons. The separation of powers then becomes a sort of "legitimizing guise".

2) Also, we can try to complement theories of the separation of powers - to create a more accurate and complex analysis of the relationships between its components and applications. We can supplement it with some other normative

26 See Ibidem, p. 38.

27 To this, cf. also E. Carolan, op. cit., p. 32.; J. Baroš, Dèlba moci jako nástroj konstitucionalismu, "Jurisprudence" 2013, no. 7, p. 16. 
thesis that will enable us to construct such applications in a predictable and rationally justifiable way.

3) The separation of powers can be completely excluded and replaced with another set of concepts that would be able to fulfil its tasks more adequately. At this point, however, the question arises as to what extent we can draw a line between this and the preceding approach, and whether the replacement of the concepts and their supplementing is not only about ceasing to use the term "separation of powers".

The following section is devoted to a brief analysis of individual approaches and some of their more specific forms.

\section{Formalism and Functionalism}

It is obvious that from the theoretical point of view the first of the approaches defined in the previous section cannot be a satisfactory solution, regardless of how (surprisingly) successfully it can work. Unfortunately, it is practice that often struggles to find transparently justifiable solutions to specific problems that are associated with the institutional applications of the separation of powers. For example, Eoin Carolan points out that U.S. judges who deal with these problems play rather a reactive than prescriptive role, and that they adapt their views of a relevant criterion so that they reflect the questions raised in the individual case. ${ }^{28}$ The theory is therefore bent according to the requirements of practice instead of guiding it. It often serves at best to provide a nice coat for an intuitively made decision, the true reasons of which we must search outside of it. All this only confirms our original concerns.

We should not settle for anything like this - we should not be content with the fact that the true reasons for decisions of state bodies can be wholly banal and rationally unjustifiable. One can hardly agree with the idea that the true reason why a party won a legal dispute was in the end that it had a nicer nose. If nothing else, we must at least try to formulate a methodology that a competent state body (most likely a court) should apply in individual cases when specifying the separation of powers and deriving its applications. This will, among other things, strengthen its legitimacy.

Sceptics, of course, may argue that even in this situation the true reasons remain banal and that we only move to another level in our considerations from which we expect to reach an easier agreement. In addition, we can criticize this effort by saying that even though we give state bodies some limitations by this if they wish, they may eventually avoid them. Institutions are indeed constrained by methodological requirements; how-

28 E. Carolan, op. cit., p. 26. 
ever, it is rather a silk ribbon that looks pretty but can be easily broken if enough pressure is exerted. In general, these requirements are not strictly binding on institutions, and they cannot be if institutions are to retain some degree of flexibility in decision-making. In spite of all this, it still seems appropriate to support the idea that it is meaningful to think about such a methodology - not only because it opens up more room for discussion about the problems of the separation of powers and their possible solutions. If nothing, it gives us some framework, although imperfect. Under the circumstances, this is the maximum possible.

In view of the above reasons, let us take a closer look at methodologically oriented approaches; first at a division between two of them that is described in detail in the English-language literature - a division into formalism and functionalism. According to Samuel W. Cooper, formalism relies on the assumption that problems associated with the separation of powers will be solved by strict interpretation of the Constitution. On the contrary, functionalism rejects the idea that these problems can be solved by examining the text constraints in the Constitution, and rather focuses on whether the behaviour of one of the components of power can disturb the balance between the powers, or whether the behaviour of one component does not interfere with the core functions of another component. ${ }^{29}$ It can be said, therefore, that while formalists place greater emphasis on separation, functionalists prefer the notion of balance. ${ }^{30}$ This also results in the typical problems of these directions - the formal doctrine fails to define the units to be separated, while the functional approach cannot deal with the issue of institutional balance. ${ }^{31}$ To this we can add that functionalism was dominant in analyses of the separation of powers made by U.S. judges for most of the 19th and 20th centuries. Formalism gained certain influence in the short phase at the end of the 1970's and in the first half of the 1980s. ${ }^{32}$ The former thus can be considered the prevailing approach.

Could we draw inspiration from these approaches in the search of approaches that are applicable in the Central European environment? If the authors of Central European constitutions were surrounded by a mystical aura, it would be worthwhile to establish institutional relations between the various state bodies (and thus to specify the principle of the separation of powers) based on their intentions. But that's not the case at all. While Americans, after a few centuries, can see their Founding Fathers as titans, we in the Central European environment, after two decades, see nothing more than ordinary people with their mistakes. The authority of the authors of constitutional documents in post-communist countries is far from being such that would lead us to a discussion of

29 S. W. Cooper, Considering "Power" in Separation of Powers, "Stanford Law Review" 1994, no. 2, p. 368 .

30 J. Baroš, op. cit., p. 15.

31 E. Carolan, op. cit., p. 26.

32 S. W. Cooper, op. cit., p. 368. 
specific applications of the separation of powers and its intentions. It is perhaps a simplified view of this problem; however, I believe that the minds of most people (at least subconsciously) rely heavily on this circumstance.

At a time when the text of the Constitution does not provide us with sufficient clues, we must begin to consider the purposes of the individual components of the separation of powers and apply such methodology that allows us to operate with different types of more open legal standards. This could involve the application of the principle of proportionality, but also the consideration of various impacts in the context of the Law \& Economics approach, or general projection of some of the methodological approaches in the field of economics. ${ }^{33}$

If we try to consider this in a more easily graspable context, we can again take a closer look at the dilemma between the application of institutional independence and the system of checks and balances. The common denominator of both components is their relationship to a certain type of intervention. The first stresses the need for its absence, while the second stresses the need for its presence. Rather we could ask, what better leads to the fulfilment of the purpose of the separation of power (good governance) in a given situation? Finding an objective answer to such a question can, however, be very difficult. Therefore, we could consider whether to interpret it in order to find out which components are associated with a lower risk. This would allow us, to a certain extent, to take into account our possible ignorance, or the impossibility of evaluating completely all the aspects of a particular case, which we would also consider risks.

In summary, we can say that under the first approach, a wide array of options opens before us which, however, are generally not very satisfactory, or that are acceptable only if the community agrees to a general need for them.

\section{Should We Innovate or Reject the Separation of Powers?}

Other possible approaches to solving the application problems of the separation of powers include efforts to innovate the separation of powers, or to replace it with another principle. How much do they really have in common and how should we evaluate them? In his work, The Evolution of Parliament, A.F. Pollard argued that the separation of powers in politics corresponds to the persistence of species in natural science and that both ignore evolution. He also criticized this principle for reducing the real complexity of human governance and for being an artificial category. ${ }^{34}$ There is a lot to be found in

33 In connection with the application of knowledge gained from economics, I find remarkable, for example, M. Silver, Economic Theory of the Constitutional Separation of Powers, " Public Choice" 1977, vol. 29, no. 1, pp. 95 - 107.

34 J. A. Fairlie, op. cit., pp. 414-417. 
these words. The way in which the individual components of the separation of powers are projected into the structure of the state cannot really came to a standstill. It therefore seems natural that the separation of powers should be subject to innovation depending on historical and social developments. If this is not the case, there is a risk that it will become a dead principle, and it cannot be surprising that practice will be governed (and as a rule it is) by a number of other factors rather than blindly following one particular doctrine ${ }^{35}$ which rather plays the role of legitimizing fiction, the main purpose of which is to preserve the status quo.

As part of the innovation process, it is not excluded that the separation of powers is so deviating from its initial concept that it will actually become a different principle. Should we be so indulgent to it and be content with this possibility or should we reject it consciously and purposefully? The radical approach is supported by the fact that too many heterogeneous components have been merged under this concept in a misleading way, creating several unnecessary confusions. On the other hand, can this not be avoided by a precise definition, and can we not then build on this purged conceptual system? Personally, I would rather be more reconciled to the separation of powers. If any concept is really to be useful, it must be accepted by the community, which is always easier when it relies, or is based, on an already well-known and accepted idea as this one is. It seems to me more appropriate to try to reformulate and supplement the concept of the separation of powers whereas this process can one day result in the creation of a new principle that will replace it. Therefore, prioritizing the second way over the third seems to be a more rational choice.

There are, of course, many approaches to correcting the separation of powers. And it is definitely not a new effort: already John A. Fairlie ${ }^{36}$ favoured more sophisticated concepts analogous to models of atoms and molecules that assume a number of different combinations. It is understandable that, given the scope of this paper, we can only provide a brief outline of them.

The first way we can follow in innovating the separation of powers consists in finding a stronger normative thesis that would create a more complete concept that would already be able to provide some specific institutional considerations. ${ }^{37}$ Eoin Carolan applies this principle when he considers replacing the classical model of the separation of powers with a model in which state institutions are identified with specific social interests. ${ }^{38}$ This is undoubtedly an interesting idea. A problem that may accompany it is

35 To compare this, e.g., Philip B. Kurland`s statement that the U.S. Constitution was born from a prudent compromise rather than from more experience than doctrine. P. B. Kurland, The Rise and Fall of the "Doctrine" of Separation of Powers, "Michigan Law Review" 1986, no. 3, p. 592.

36 J. A. Fairlie, op. cit., p. 435.

37 E. Carolan, op. cit., p. 33.

38 Ibidem, p. 257. 
the unexplained relationship between an institution and a social interest. The requirement that an institution should originate based on a social interest seems to be justified. The difficulty may lie in that most institutions, (and thus also the institutional structure of the state as a whole), reflect a certain tradition. As social conditions gradually evolve, these interests are modified or disappear, and institutions then begin to live their own lives to some extent; but above all, they themselves begin to participate in the constitution of specific social interests. Sometimes, therefore, it may be difficult to separate the two (within one process).

Victoria Nourse proposes another way that is based on a more comprehensive analysis. Nourse states that the U.S. Constitution not only describes the U.S. system of state bodies as, "a compendium of the executive, legislative and judicial powers, but it also creates that government by constituting electoral relationships that confer political authority." ${ }^{9} 9$ The horizontal separation of powers that separates these powers through functional lines is then incomplete if it does not consider the vertical separation of powers. In Nourse's concept, this means the relationships between the system of state bodies and constituency. ${ }^{40}$ Changes in these vertical relationships also have an effect on the horizontal relationships of the separation of powers. As an example, Nourse mentions a situation where senators would be elected by congressmen, which would fundamentally change the relationship between the two institutions. ${ }^{41}$ Therefore, in order for the separation of powers to be complete, it is necessary to take account of the relationships that each institution has to those groups that constitute it. Such an approach allows us, in its consequences, to free ourselves from arguments about whether we can really define the legislature, judiciary, and executive. ${ }^{42}$ Moreover, Nourse further states that verticalism seeks to identify constitutional harm in something more than just excessive power, disturbed balance, or mixing of functions. Verticalism identifies the constitutional harm in that the voice of certain electoral groups is silenced or over-emphasized. The fact that the Supreme Court should not decide on the issue of war is not due to the fact that such decision-making does not belong to the judiciary but rather because it would limit too much the influence of the electorate at the level of national and local constituencies in deciding on such issues. The Supreme Court could then go to war without the people, the decision would become elitist, and democracy would become aristocracy. ${ }^{43}$ Finally, Nourse admits that even this approach is not ideal. Yet, it seems more appropriate than some competing alternatives. ${ }^{44}$

39 V. Nourse, The Vertical Separation of Powers, "Duke Law Journal” 1999, no. 3, p. 751.

40 Ibidem, pp. 751 - 752.

41 V. Nourse, op. cit., p. 763.

42 Ibidem, p. 752.

43 Ibidem, p. 759.

44 Ibidem, p. 789. 
In my opinion, however, a question remains whether such a more sophisticated analysis is able to give us sufficient clues to address some of the above-mentioned application problems, such as the prioritization of institutional independence or the system of checks and balances. I am afraid that it rather allows us to make a more complete description of the current system, but it does not give us enough reasons for a (prescriptive) solution to some new problems.

Finally, we can summarize that innovative approaches to the separation of powers obviously suffer from their specific problems. However, in the context of possible approaches, we can still consider them the most appropriate solutions. Even if they fail to solve the relevant application problems completely, and there would still be open space for discretion by a state body, (in the spirit of the first approach), it would be at least slightly reduced. The separation of powers would then become a more debated issue and deciding on it would at least become more transparent.

\section{Conclusion}

The thesis that the separation of powers cannot save us by itself, no matter how wellthought it can be, sounds banal. Still, we are not far from the truth when we conclude that a number of objections against it relate to the many exaggerated expectations that people usually have. Indeed, for the proper functioning of the state it is necessary to have a certain social equilibrium within it and not just an institutional one. The separation of functions is not rigorously implemented anywhere, and neither has it been in the past. Indeed, the relationships between institutional independence and the system of checks and balances are too open to allow us to fine-tune every detail of the system of state bodies with absolute precision. It is the last of the above-mentioned objections that should worry us the most. Is not the separation of powers a too vague concept to have any meaning in our discussions? And not only theoretical, but also practical discussions.

The separation of powers is undoubtedly a confusing concept. If we imagine a sovereign who holds all the power in his hands, the idea of the separation of powers among multiple agents seems easy to understand. It could be (and has been) a catchy political slogan. Difficulties arise if we begin to perceive it as a theoretical concept that should structurally define clearly defined phenomena. At that point, many objections start to pop up that were described in more detail in this paper. The described problem of the uncertainty of the separation of powers has different outcomes. We have suggested three different approaches here. The first one was based on the thesis that, ultimately, all decisions about it are arbitrary - at least in the sense that they are determined by elements that we could consider legal. Yet, in practice, we should rather plead for the second approach - to try to innovate the separation of powers and create its deeper concepts. 
Attempting to find at least a partial agreement on some of them is still better than to simply state its unjustifiability. There is a difference between the requirements of the truth of some theory, and practical needs.

Yes, we can eventually agree with sceptics like John A. Fairlie who wrote that, "Acleancut scientific analysis of governmental functions as the basis for a fixed plan of political organization is probably impossible." 45 But that does not mean that the separation of powers has no meaning. If we want to properly evaluate its significance, we must measure it not only using ideal gauges but also real alternatives we can use. And these alternatives often represent similarly unclear clues. In short, we live in a very complex world, and our knowledge has its limits. In our effort to achieve good governance, we therefore must make do with those instruments that we have available, and the separation of powers is, despite all its imperfections, one of them. Although it is not capable of ensuring good governance by itself alone, it might be too difficult to achieve this ideal without the separation of powers. Although we really do not know much about functionality of this concept, the risks we could face after rejecting it seem too high. So, it seems more reasonable to keep a friendly attitude toward the separation of powers.

\section{Literature}

Baroš J., Délba moci jako nástroj konstitucionalismu, Jurisprudence 2013, no. 7.

Carolan E., The New Separation of Powers: A Theory for the Modern State, New York 2009. Claus L., Montesquieu's Mistakes and the True Meaning of Separation, Oxford Journal of Legal Studies 2005, no. 3.

Cooper S. W., Considering "Power" in Separation of Powers, Stanford Law Review 1994, no. 2 .

Fairlie J. A., The Separation of Powers, "Michigan Law Review" 1923, no. 4.

Hamilton, A., Madison, J., Jay J., The Federalist, Indianapolis 2005.

Kurland P. B., The Rise and Fall of the "Doctrine" of Separation of Powers, "Michigan Law Review"1986, no. 3.

Magill M. E., The Real Separation in Separation of Powers Law, "Virginia Law Review" 2000, no. 6.

Montesquieu Ch., The Spirit of Laws, Kitchener 2001.

Nourse V., The Vertical Separation of Powers, “Duke Law Journal” 1999, no. 3.

Tomoszek M., Délba moci jako podstatná náležitost demokratickébo právníbo státu, in Dèlba moci. Sbornik príspèrviu sekce ústavniho práva, prednesených na mezinárodni vèdecké konferenci Olomoucké prárnické dny 2013, ed. Jirásek, J., Olomouc 2014.

45 J. A. Fairlie, op. cit., p. 431. 
224 | Adam Mickiewicz University Law Review

Vile M. J. C., Constitutionalism and the Separation of Powers, Indianopolis 1998.

Waldron J., Political Political Theory. Essays on Institutions, Cambridge-London 2016.

Weyr F., Československé právo ústavní, Praha 1937.

Weyr F. Teorie práva, Praha 2015.

Zoulík F., Soudy a soudnictví, Praha 1995.

SUMMARY

\section{Is Separation of Powers a Useless Concept? Part II: Tripartite System Criticism and Application Problems}

In this paper, the author raised the question of whether the separation of powers is a useless concept. It summarizes some critical arguments against the tripartite separation of powers. The paper deals with application issues related to the separation of powers and distinguishes several attitudes toward them, which it then analyses in more detail. Great attention is dedicated to formalism and functionalism. Eventually, the author wonders whether it would be better to innovate the idea of separation of powers, or to dismiss and replace it with some other principle. He concludes that the separation of powers has problems, but we need to evaluate this idea in relation to its possible alternatives. In such a light it still sounds promising.

Keywords: Separation of powers; state functions; tripartite separation of powers; formalism; functionalism; political theory.

Martin Hapla, Faculty of Law, Masaryk University, Veveři 70, Brno 611 80, Czech Republic, e-mail: martinhapla@gmail.com. 